\begin{tabular}{|l|l|l||}
\hline \multicolumn{2}{|c|}{ PublisherInfo } \\
\hline \hline PublisherName & $:$ & BioMed Central \\
\hline \hline PublisherLocation & $:$ & London \\
\hline \hline PublisherImprintName & $:$ & BioMed Central \\
\hline \hline
\end{tabular}

\title{
Red squirrels in Britain
}

\begin{tabular}{|l|l|l||}
\hline \multicolumn{2}{|c|}{ ArticleInfo } \\
\hline \hline ArticleID & $:$ & 4208 \\
\hline \hline ArticleDOI & $:$ & $10.1186 /$ gb-spotlight-20010925-01 \\
\hline \hline ArticleCitationID & $:$ & spotlight-20010925-01 \\
\hline \hline ArticleSequenceNumber & $:$ & 279 \\
\hline \hline ArticleCategory & $:$ & Research news \\
\hline \hline ArticleFirstPage & $:$ & 1 \\
\hline \hline ArticleLastPage & $:$ & 2 \\
\hline \hline & & RegistrationDate : 2001-09-25 \\
ArticleHistory & $:$ & OnlineDate $\quad$ 2001-09-25 \\
\hline \hline ArticleCopyright & $:$ & BioMed Central Ltd2001 \\
\hline \hline ArticleGrants & $:$ & \\
\hline \hline ArticleContext & $:$ & 130592211 \\
\hline \hline
\end{tabular}




\section{Jonathan B Weitzman}

Email: jonathanweitzman@hotmail.com

Red squirrels (Sciurus vulgaris) thrive in the north of England and Scotland and occupy a patchwork of highly fragmented woodland habitats. In the September 21 Science, Marie Hale and colleagues from the University of Newcastle, UK, report a genetic investigation of the impact of habitat fragmentation on British red squirrel populations (Science 2001, 293:2246-2248). They assembled over 100 squirrel samples collected between 1918 and 2000 and analysed four polymorphic microsatellite loci for each specimen. Individual squirrels were assigned to populations on the basis of which wood they were collected in. Hale et al. could separate squirrel populations into three genetic and geographical groups: northern, western and eastern. They found that Cumbrian squirrels changed dramatically in the 1980s from a western to northern genotype. This was linked with the planting of a large conifer forest, Kielder Forest, which resulted in a 'defragmentation' of the landscape. This study shows how genes can leapfrog through habitat patches that serve as a network of 'stepping stones' and it highlights how human-driven changes to the landscape can have a dramatic affect on the speed of gene flow across hundreds of kilometers.

\section{References}

1. Sciurus vulgaris, [http://animaldiversity.ummz.umich.edu/accounts/sciurus/

s._vulgaris\$narrative.html]

2. Science, [http://www.sciencemag.org]

3. University of Newcastle, [http://www.ncl.ac.uk]

4. Kielder Forest, [http://www.kielder.org] 